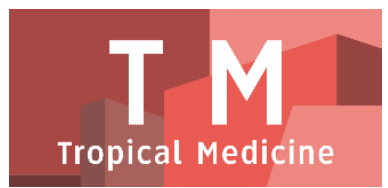

PAPER - OPEN ACCESS

\title{
IgG Anti-Toxoplasma pada Cairan Otak Pasien Terinfeksi HIV $\&$ AIDS dengan Meningitis
}

\author{
Author : Yunilda Andriyani \\ DOI $\quad: 10.32734 / \mathrm{tm} . \mathrm{v} 1 \mathrm{i} 1.30$ \\ Paper Page : $132-141$
}

Volume 1 Issue 1 - 2018 TALENTA Conference Series: Tropical Medicine (TM)

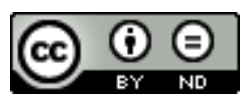

This work is licensed under a Creative Commons Attribution-NoDerivatives 4.0 International License.

Published under licence by TALENTA Publisher, Universitas Sumatera Utara
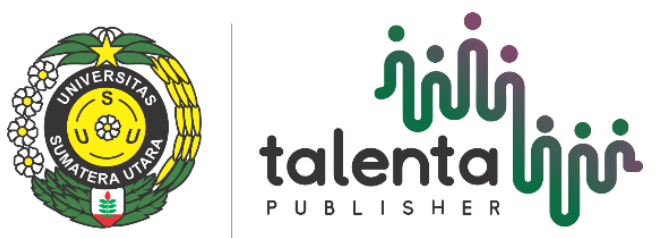


\title{
talentạlo \\ Available online at https://talentaconfseries.usu.ac.id
}

\section{IgG Anti-Toxoplasma pada Cairan Otak Pasien Terinfeksi HIV \& AIDS dengan Meningitis}

\author{
Yunilda Andriyani ${ }^{a^{*}}$, Agnes Kurniawan ${ }^{\mathrm{b}}$, Ika Puspa Sari ${ }^{\mathrm{b}}$, Retno Wahyuningsih ${ }^{\mathrm{b}}$ \\ ${ }^{a}$ Departemen Parasitologi, Fakultas Kedokteran Universitas Sumatera Utara, 20155, Indonesia \\ ${ }^{b}$ Departemen Parasitologi, Fakultas Kedokteran Universitas, 20155, Indonesia \\ ayandriyani@yahoo.com
}

\begin{abstract}
Abstrak
Toksoplasmosis diperkirakan telah menginfeksi sepertiga populasi dunia dan dapat mengancam jiwa pasien dengan imunokompromi. Ensefalitis toksoplasma (ET) terjadi akibat reaktivasi infeksi laten $T$. gondii yang sering terjadi pada pasien AIDS, terutama stadium akhir. Untuk menegakkan diagnosis pasti pada pasien AIDS dengan kelainan SSP sangatlah sulit. Diagnosis ET ditegakkan hanya berdasarkan asumsi dari gejala klinis, gambaran radiologi, dan respon terhadap terapi yang diberikan. Pemeriksaan kadar IgG dari cairan organ masih jarang dilakukan. Sampel cairan otak diperoleh dari 50 pasien HIV \& AIDS yang dikumpulkan sejak Januari 2013 hingga 2014 di Laboratorium Parasitologi FKUI. Kadar CD4 ${ }^{+}$, gejala klinis, hasil radiologi, diagnosis klinis, riwayat terapi profilaksis ko-trimoksazol, dan analisis cairan otak, diperoleh dari rekam medik.Dari 50 sampel, diperoleh hasil 24 (48\%) positif dan 26 (52\%) negatif IgG anti-Toxoplasma. Dari IgG positif, terdapat 5 (20,83\%) dengan kadar tinggi, dan 19 (79,17\%) dengan kadar IgG rendah. Tidak ada perbedaan bermakna antara kadar IgG antiToxoplasma dengan hasil radiologi, diagnosis klinis, maupun riwayat terapi profilaksis ko-trimoksazol. Diperoleh korelasi negatif antara kadar $\mathrm{CD}^{+}$dan IgG anti-Toxoplasma, walaupun kekuatannya sangat lemah. Berdasarkan hasil radiologi, diperoleh sensitivitas $56 \%$, spesifisitas $57 \%$, nilai duga positif $41 \%$, dan nilai duga negatif $71 \%$.
\end{abstract}

Kata Kunci : cairan otak; Ensefalitis Toksoplasma; AIDS; IgG anti-Toxoplasma

\section{Pendahuluan}

Toxoplasma gondii merupakan protozoa intraselular obligat yang tersebar di seluruh dunia. Bereplikasi pada hampir seluruh sel berinti dalam tubuh pejamu. Infeksi yang diakibatkannya disebut toksoplasmosis, dan diperkirakan sekitar sepertiga populasi dunia terinfeksi T.gondii. Prevalensi dari tiap negara di dunia berbeda, mulai dari $10 \%$ sampai $80 \%$. Prevalensi seropositif toksoplasmosispada individu imunokompeten di Asia Tenggara berkisar antara 2-75\%, sedangkan di Jakarta berkisar 70\%. Biasanya seseorang diketahui telah terinfeksi T. gondii hanya dari pemeriksaan serologi darah dan bukan akibat gejala klinis yang ditimbulkannya. Toksoplasmosis akan menjadi masalah bahkan dapat mengancam jiwa bila infeksi terjadi pada orang imunokompromi, misalnya pada orang yang mendapat terapi imunosupresi atau penderita AIDS.Ensefalitis toksoplasma (ET) adalah inflamasi di sistem saraf pusat (SSP) yang terjadi akibat reaktivasi infeksi laten $T$. gondii, dan merupakan masalah yang sering terjadi pada pasien AIDS, terutama pada stadium akhir. Pada SSP, akan dijumpai gambaran ensefalitis nekrotik multifokal yang akan berkembang menjadi abses parenkim dengan nekrosis yang dikelilingi sel-sel inflamasi. Infeksi ini cukup berbahaya dan mengancam jiwa seiring dengan menurunnya sistem imun yang semakin berat. 
Diperkirakan sekitar 10-50\% pasien AIDS yang menderita toksoplasmosis akan berlanjut menjadi ET. Hal itu bergantung dari jumlah kasus toksoplasmosis di daerah tersebut.Mengingat angka seropositive $T$. gondii yang cukup banyak di Indonesia, khususnya di Jakarta, maka kemungkinan penderita AIDS yang akan mengalami ET akan semakin tinggi. Di RSCM, Jakarta, kasus ET mencapai 35\% dari seluruh kasus sehubungan infeksi SSP pada penderita AIDS. Diagnosis ET umumnya ditegakkan hanya berdasarkan asumsi dari gejala klinis, gambaran radiologi, dan respons terhadap terapi yang diberikan. Pemeriksaan radiologi seperti computerized tomography (CTscan) dan magnetic resonance imaging (MRI) dapat mendeteksi lesi di otak yang mungkin merupakan ET, akan tetapi sering dijumpai gambaran yang hampir mirip dengan kelainan pada otak lainnya, sehingga menyulitkan penegakan diagnosis.

Pada pasien AIDS dengan defisit neurologis, punksi lumbal dilakukan untuk diagnosis. Akan tetapi, punksi lumbal pada ET jarang dilakukan karena berdasarkan asumsi bahwa infeksi terjadi pada otak dan tidak berhubungan dengan cairan otak, serta kekhawatiran akan terjadi proses desak-ruang akibat tindakan tersebut. Berdasarkan studi di RS Hasan Sadikin, Bandung, yang memeriksa CSS pasien- pasien yang diduga menderita meningitis dengan teknik PCR, ternyata 32,8\% pasien AIDS positif T.gondii. Menurut Colombo, dkk (2005), kadar IgG antiToxoplasma yang tinggi mengindikasikan terjadinya ET atau pasien tersebut berisiko mengalami infeksi tersebut.

Oleh karena masih jarangnya penelitian yang menggunakan CSS untuk penegakan diagnosis ET dan untuk mengetahui apakah kadar IgG anti-Toxoplasma pada CSS bermakna dalam menegakkan dosis ET, maka penelitian mengenai hal tersebut dilakukan pada pasien HIV \& AIDS dengan dugaan meningitis.

\section{Metode Penelitian}

Subyek penelitian adalah pasien AIDS yang diduga meningitis dan dirawat di Rumah Sakit Cipto Mangunkusumo (RSCM), Jakarta. Sampel penelitian adalah cairan otak pasien AIDS tersebut yang merupakan koleksi Divisi Mikologi Departemen Parasitologi FKUI sejak tahun 2013 hingga Maret 2015, dan disimpan pada suhu $-20^{\circ} \mathrm{C}$. Pengambilan sampel dilakukan secara consecutive sampling, yaitu sampel yang bisa ditelusuri data medisnya di bagian rekam medik RSCM. Dari seluruh sampel yang ada, sebanyak 50 sampel memenuhi kriteria penelitian.

Data yang dibutuhkan berasal dari rekam medis pasien meliputi usia, jenis kelamin, gambaran radiologi, kadar CD4, riwayat terapi, dan diagnosis sementara. Kadar CD4+ yang dimasukkan sebagai sampel adalah $<200 \mathrm{sel} / \mathrm{mm} 3$. Sampel yang juga dicurigai menderita ET oleh klinisi dan diambil cairan otaknya, juga dimasukkan dalam sampel penelitian.

Pemeriksaan IgG anti-Toxoplasma menggunakan kit Anti-Toxoplasma gondii ELISA (IgG) EUROIMMUN ${ }^{\mathrm{TM}}$ (no. kat EI 2410-9601G, Lübeck, Germany) dan mengikuti prosedur yang tercantum dalam kit.

Data ditampilkan dalam bentuk tabel dan grafik, dan diolah dengan menggunakan SPSS versi 20.0 untuk menilai hubungan antara parameter-parameter terkait. Cat Maker digunakan untuk menilai uji diagnostic

\section{Hasil}

Subyek penelitian terutama didominasi oleh laki-laki 45 orang (90\%), sedangkan perempuan 5 orang (10\%). Umur pasien pada penelitian ini bervariasi, dengan usia terendah 20 tahun dan tertinggi 57 tahun, dan median 34 tahun. Karakteristik subyek penelitian dapat dilihat pada Tabel 1 . 
Tabel 1. Karakteristik Subjek Penelitian

\begin{tabular}{llll}
\hline & $\mathrm{n}(\%)$ & $\begin{array}{l}\text { Median } \mathrm{CD}^{+} \\
\left(\mathrm{sel} / \mathrm{mm}^{3}\right)\end{array}$ & $\begin{array}{l}\mathrm{CD}^{+}\left(\mathrm{sel} / \mathrm{mm}^{3}\right) \\
\min -\mathrm{max}\end{array}$ \\
\hline $\begin{array}{l}\text { Jenis Kelamin } \\
\text { Laki-laki }\end{array}$ & $45(90)$ & 40 & $1-198$ \\
$\quad \begin{array}{l}\text { Perempuan } \\
\text { Umur }\end{array}$ & $5(10)$ & 8 & $3-153$ \\
$20-30$ & $10(20)$ & 24,5 & \\
$31-45$ & $38(76)$ & 43 & $5-197$ \\
$>45$ & $2(4)$ & 100,5 & $1-198$ \\
\hline
\end{tabular}

Dari seluruh subyek penelitian, hanya 36 orang yang diketahui faktor risikonya mendapat infeksi HIV \& AIDS. Dari seluruh faktor risiko, Intravena drug users (IDUs) merupakan faktor risiko terbesar. Umumnya faktor risiko tidak berdiri sendiri dan merupakan gabungan dari beberapa lainnya. Pada promiskuitas tidak diketahui apakah berasal dari hubungan heteroseksual atau homoseksual. Informasi faktor risiko ini umumnya diperoleh dari pihak kedua (alloanamnesa), karena subyek penelitian umumnya sudah sulit untuk dimintai keterangan.

Tabel 2. Faktor Resiko Menderita HIV \& AIDS

\begin{tabular}{ll}
\hline Faktor Resiko & $\mathrm{n}(\%)$ \\
\hline Seksual (Heteroseksual/Homosexual) & $11(22 \%)$ \\
IDU & $16(32 \%)$ \\
Tranfusi Darah & 0 \\
Tranmisi Perinatal & 0 \\
Lain-lain & $8(16 \%)$ \\
Tidak diketahui & $14928 \%)$ \\
\hline
\end{tabular}

Data analisis CSS subyek penelitian (16 dari 50 sampel) yang ada pada rekam medis, dapat dilihat pada Tabel 3.

Tabel 3. Analisis Cairan Otak $(\mathrm{n}=16)$

\begin{tabular}{lll}
\hline & Nilai Minimum - & Nilai Normal \\
& Maksimum Sampel & \\
\hline Sel Polimorfonuklear (PMN) & $0-441$ & $0-5 \mathrm{sel} / \mu \mathrm{L}$ \\
Sel Mononuklear (MN) & $6-160$ & \\
Kadar Glukosa CSS & $22-61$ & $<140 \mathrm{mg} / \mathrm{dL}$ \\
Kadar Glukosa Serum & $61-127$ & $15-45 \mathrm{mg} / \mathrm{dL}$ \\
\hline
\end{tabular}


Pemeriksaan kadar IgG anti-Toxoplasma pada penelitian ini ternyata tidak terdistribusi normal $(\mathrm{p}=0,00 ; \mathrm{p}<$ 0,05), dimana kadar terendah 0 IU dan tertinggi 245,35 IU, dengan nilai tengah 9,30 IU.

Nilai cut-off positif ditetapkan $\geqslant 11$ IU. Dari hasil pemeriksaan didapatkan sampel positif IgG anti - Toxoplasma 24 (48\%), dan negatif 26 (52\%). Berdasarkan studi oleh Derouin, dkk, (1996) [8] maka pada penelitian ini kadar IgG anti-Toxoplasma juga dibagi menjadi tiga, yaitu negatif (<11 IU), rendah ( $\geqslant 11-150 \mathrm{IU})$, dan tinggi ( $>150 \mathrm{IU})$. Dari hasil positif ditemukan 5 (20,83\%) tinggi, dan 19 (79,17\%) rendah. Gambaran kadar IgG anti-Toxoplasma terhadap analisis cairan otak, kadar CD4+, dan gejala neurologis yang dialami subyek penelitian, terangkum dalam Tabel 4.

Tabel 4. Analisis Cairan Otak, Kadar $\mathrm{CD}^{+}$, dan Gejala Neurologis berdasarkan IgG Anti-Toxoplasma

\begin{tabular}{|c|c|c|c|c|c|c|}
\hline \multirow[b]{4}{*}{$\begin{array}{l}\text { Analisis CSS Sel PMN } \\
(\mathrm{sel} / \mu \mathrm{L})\end{array}$} & \multicolumn{6}{|c|}{ IgG Anti-Toxoplasma } \\
\hline & \multicolumn{2}{|l|}{ Tinggi } & \multicolumn{2}{|c|}{ Rendah } & \multicolumn{2}{|c|}{ Negatif } \\
\hline & $\begin{array}{l}\text { Median } \\
(\min -\max )\end{array}$ & $\mathrm{N}$ & $\begin{array}{l}\text { Median } \\
(\min -\max )\end{array}$ & $\mathrm{N}$ & $\begin{array}{l}\text { Median } \\
(\min -\max )\end{array}$ & $\mathrm{n}$ \\
\hline & $3(0-16)$ & 5 & $10(1-10)$ & 5 & $1,5(0-441)$ & 6 \\
\hline Sel MN (sel/ $/ \mu \mathrm{L})$ & $89,5(9-160)$ & 5 & $9(6-9)$ & 5 & $12(6-49)$ & 6 \\
\hline Protein $(\mathrm{mg} / \mathrm{dL})$ & $203,5(25-442)$ & 5 & $30(20-45)$ & 5 & $89,5(6-202)$ & 6 \\
\hline Glukosa CSS (mg/dL) & $38(23-61)$ & 5 & $52(43-53)$ & 5 & $35(22-54)$ & 6 \\
\hline $\begin{array}{l}\text { Glukosa Serum } \\
(\mathrm{mg} / \mathrm{dL})\end{array}$ & $103(88-127)$ & 4 & $94(92-111)$ & 3 & $83,5(61-122)$ & 4 \\
\hline $\mathrm{CD}^{+}\left(\mathrm{sel} / \mathrm{mm}^{3}\right)$ & $26(10-168)$ & 5 & $31(1-192)$ & 19 & $54,5(1-198)$ & 26 \\
\hline \multicolumn{7}{|l|}{ Gejala Neurologis } \\
\hline Sakit Kepala & & 5 & & 12 & & 14 \\
\hline $\begin{array}{l}\text { Penurunan Kesadaran } \\
\text { Kelemahan Sisi Tubuh }\end{array}$ & & 4 & & 9 & & 11 \\
\hline $\begin{array}{l}\text { Gangguan Fungsi } \\
\text { Luhur }\end{array}$ & & 1 & & 4 & & 10 \\
\hline Kejang & & 1 & & 1 & & 4 \\
\hline Mual Muntah & & 0 & & 3 & & 4 \\
\hline \multirow[t]{2}{*}{ Gangguan Pandangan } & & 1 & & 2 & & 5 \\
\hline & & 0 & & 4 & & 3 \\
\hline
\end{tabular}

Pada studi ini, juga dilihat hasil radiologi, diagnosis klinis, riwayat pemberian anti retroviral (ARV), pemberian ko-trimoksazol, dan hasil pemeriksaan jamur Cryptococcus yang telah dilakukan sebelumnya. Hasil pemeriksaan radiologi dibagi menjadi dua, yaitu yang positif mengarah ET dan tidak mengarah ET. Dari 50 sampel, ada empat sampel yang tidak disertai hasil radiologi, karena subyek telah meninggal sebelum dilakukan pemeriksaan. Diagnosis klinis diperoleh dari surat pengantar dan/atau rekam medis pasien. Walaupun pasien diduga sebagai meningitis, diagnosis ET dijadikan sebagai diagnosis banding atau dianggap bersamaan dengan infeksi bakteri atau jamur.

Riwayat pemberian anti retroviral (ARV) diketahui dari catatan dalam rekam medis. Berdasarkan hal itu, maka riwayat ARV dibagi menjadi tiga, yaitu belum, sedang, dan putus terapi ARV. Riwayat pemberian ko-trimoksazol dibagi menjadi tiga kategori yaitu profilaksis; pernah atau sedang diberi terapi profilaksis ko-trimoksazol, empiris; sedang diberikan terapi yang sesuai dengan prosedur terapi untuk ensefalitis toksoplasma, dan tidak diketahuiberdasarkan rekam medis yang diperoleh. Untuk melihat gambaran beberapa variabel tersebut berdasarkan tinggi rendahnya IgG anti-Toxoplasma, dapat dilihat pada Tabel 5 dan Tabel 6. 
Tabel 5. IgG Anti-Toxoplasma pada Beberapa Variabel Pemeriksaan

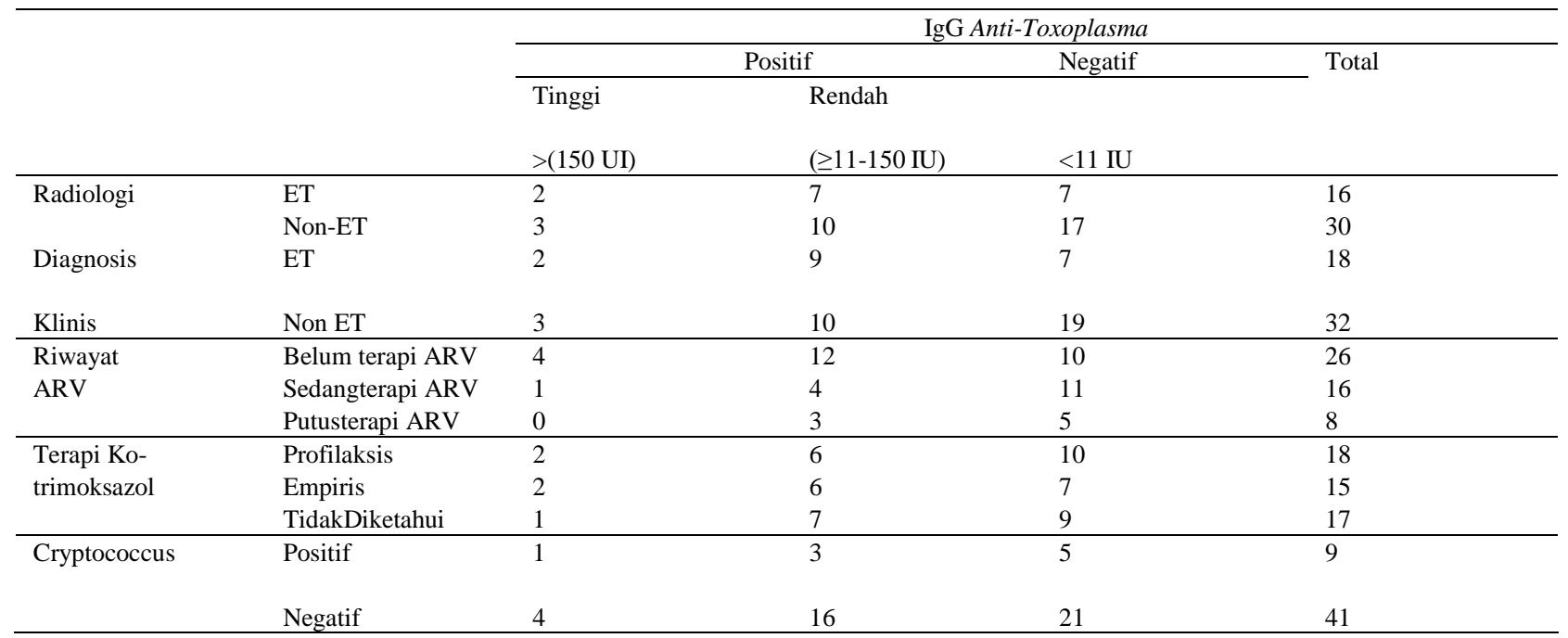

Tabel 6. Kadar IgG Anti-Toxoplasma dikaitkan dengan Radiologi, Diagnosis Klinis, Terapi KOTrimoksazol, dan Riwayat ARV

\begin{tabular}{|c|c|c|c|}
\hline & & \multicolumn{2}{|c|}{ IgG Anti-Toxoplasma (IU) } \\
\hline & & Median & Min-Max \\
\hline \multirow[t]{2}{*}{ Radiologi } & ET & 22,25 & $0-245,35$ \\
\hline & Non-ET & 4,29 & $0-200,53$ \\
\hline \multirow[t]{2}{*}{ Diagnosis Klinis } & ET & 31,89 & $0-245,35$ \\
\hline & Non ET & 0 & $0-200,35$ \\
\hline \multirow[t]{3}{*}{ Terapi Ko-trimoksazol } & Profilaksis & 0 & $0-171,5$ \\
\hline & Empiris & 16,6 & $0-245,35$ \\
\hline & TidakDiketahui & 10,08 & $0-200,53$ \\
\hline \multirow[t]{3}{*}{ Riwayat ARV } & Belum & 23,32 & $0-245,35$ \\
\hline & Sedang & 0 & $0-200,53$ \\
\hline & Putus & 0 & $0-140,59$ \\
\hline
\end{tabular}

Untuk melihat hubungan antara hasil radiologi dan IgG anti-Toxoplasma, dilakukan uji Mann Whitney (karena kadar IgG anti-Toxoplasma tidak terdistribusi normal), didapati nilai $\mathrm{p}=0,243$ ( $p>0,05$ ), yang berarti secara statistik tidak terdapat perbedaan bermakna antara kadar IgG anti-Toxoplasma dengan hasil radiologi mengarah ET.

Untuk melihat hubungan antara diagnosis klinis dan IgG anti-Toxoplasma, dilakukan uji Mann Whitney, didapatkan $\mathrm{p}=0,094$ ( $>>0,05)$, yang berarti secara statistik tidak ada perbedaan bermakna antara kadar IgG antiToxoplasma dengan diagnosis klinis ET.

Untuk riwayat pemberian ARV dan kadar IgG anti-Toxoplasma, juga secara statistik tidak didapati perbedaan bermakna ( $\mathrm{p}=0,158, \mathrm{p}>0,005)$.

Oleh karena tidak diketahui luaran hasil terapi empiris, maka ingin dilihat hubungan antara pemberian terapi profilaksis (ko-trimoksazol) dengan kadar IgG anti-Toxoplasma. Berdasarkan hasil uji Mann Whitney, dengan $\mathrm{p}=$ 0,386 ( $\mathrm{p}>0,05$ ), maka secara statistik tidak ada perbedaan bermakna antara kadar IgG anti-Toxoplasma dengan riwayat pemberian ko-trimoksazol.

Berdasarkan kadar CD4+, dilakukan uji komparatif numerik lebih dari dua kelompok tidak berpasangan. Hasil uji Kruskal Wallis didapatkan nilai $\mathrm{p}=0,819$ ( $\mathrm{p}>0,05)$, yang berarti secara statistik tidak ada perbedaan bermakna antara kadar CD4+ dan kadar IgG anti-Toxoplasma. Walaupun demikian, berdasarkan uji korelasi Spearman, didapati nilai $-0,149$, yang menunjukkan adanya korelasi terbalik, walaupun kekuatan korelasinya sangat lemah. (Gambar 1) 


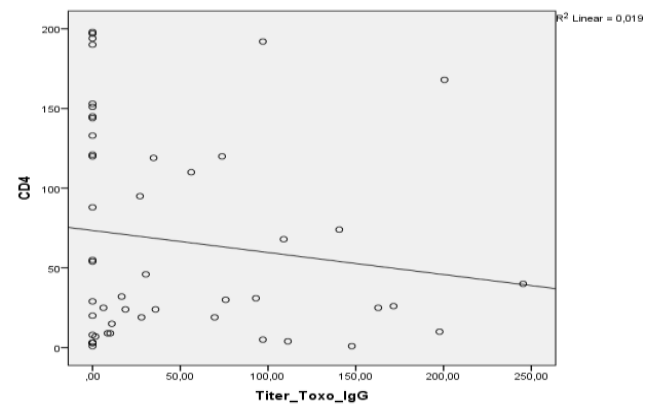

Gambar 1. Grafik Korelasi CD4+ dan IgG anti-Toxoplasma

Untuk menilai apakah pemeriksaan IgG dari cairan otak dapat dijadikan sebagai alat diagnostik, maka dilakukan penilaian untuk uji diagnostik. Sebagai standar baku untuk uji diagnostik ini adalah hasil pemeriksaan radiologi yang mengarah toksoplasmosis. Kadar IgG $\geq 11$ IU dianggap sebagai nilai positif diagnosis toksoplasmosis.

Tabel 7. Tabel 2x2 Uji Diagnostik IgG anti-Toxoplasma

\begin{tabular}{|c|c|c|c|c|}
\hline \multirow{3}{*}{$\begin{array}{l}\text { Kadar IgG } \\
\geqslant 11 \mathrm{IU}\end{array}$} & & \multicolumn{2}{|c|}{ RadiologiToxoplasmosis } & \multirow[t]{2}{*}{ Total } \\
\hline & & Positif & Negatif & \\
\hline & Negatif & 7 & 17 & 24 \\
\hline
\end{tabular}

Dari Tabel 7, diperoleh sensitivitas 56\%, spesifisitas 57\%, nilai duga positif (positive predictive value) $41 \%$, dan nilai duga negatif (negative predictive value) $71 \%$.

\section{DISKUSI}

Subyek penelitian didominasi oleh jenis kelamin laki-laki yaitu 45 orang (90\%), dan perempuan hanya 5 orang (10\%). Berdasarkan laporan dari Kementerian Kesehatan RI September 2014, penderita AIDS laki-laki lebih banyak dibandingkan perempuan yaitu 65\% dan 35\%.41 Umur subyek penelitian berada pada usia 20 sampai 57 tahun, dengan nilai tengah 34 tahun. Hasil ini juga sesuai dengan laporan statisitik Kementerian Kesehatan RI 2014 bahwa rentang usia penderita AIDS usia produktif (20-59 tahun) berkisar 91\% dimana usia terbanyak berada pada kelompok umur 20-39 tahun (74\%).Penderita AIDS yang dimaksud dalam penelitian ini adalah yang menderita HIV stadium 4. Padapenelitian ini, kadar terendah $1 \mathrm{sel} / \mathrm{mm} 3$ dan tertinggi $198 \mathrm{sel} / \mathrm{mm} 3$, dengan nilai tengah 31,5 sel/mm3. Hal ini sesuai dengan studi oleh Derouin, dkk (1996) [8] yang menyatakan pemeriksaan untuk menilai kejadian ET sebaiknya dilakukan pada mereka dengan kadar CD4+ kurang dari $200 \mathrm{sel} / \mathrm{mm} 3$ untuk melihat kemungkinan reaktivasi subklinikal kista dorman Toxoplasma.

Pada analisis cairan otak, tingginya jumlah sel PMN dan MN menandakan adanya infeksi pada otak, baik itu meningitis atau ensefalitis. Pada penelitian ini dijumpai peningkatan jumlah sel MN pada kadar IgG tinggi dibanding kadar rendah dan negatif. Kemungkinan karena pada toksoplasmosis, sel-sel MN, terutama makrofag, yang lebih berperan dalam eliminasi infeksi $T$. gondii. Untuk menilai adanya proses patologi di otak juga bisa berdasarkan rasio glukosa CSS/serum.Menurut Deisenhammer, dkk, (2011) [9] bila rasio glukosa tersebut kurang dari 0,4-0,5 menandakan terjadi proses patologi pada otak, yang mengindikasikan terjadi infeksi mikroorganisme seperti bakteri dan jamur. Pada penelitian ini, rasio glukosa CSS/serum diambil dari median masing-masing dan 
tampak adanya penurunan rasio yang cukup rendah pada sampel dengan kadar IgG tinggi $(0,37)$. Kemungkinan ini bisa dijadikan sebagai penanda adanya infeksi, khususnya ET, pada SSP.

Secara statistik ternyata tidak dijumpai perbedaan atau hubungan antara kadar IgG anti-Toxoplasma dengan hasil radiologi atau pun diagnosis klinis. Walaupun demikian, median kadar IgG pada sampel dengan hasil pencitraan mengarah ET lebih tinggi dibandingkan yang bukan ET. Begitupun pada sampel yang diagnosis klinisnya dicurigai ET, memiliki median kadar IgG yang lebih tinggi. Berdasarkan riwayat pemberian ARV, walaupun hasilnya secara statistik tidak ada hubungan, perlu diperhatikan median IgG pada subyek yang belum mendapat ARV, yaitu 23,32 IU, sedangkan median pada sedang mendapat ARV dan putus terapi 0 IU.

Pada penelitian, walaupun tidak ditemukan perbedaan antara kadar CD4+ dan IgG anti-Toxoplasma, uji korelasi negatif antara kadar CD4+ dan IgG menunjukkan semakin rendah kadar CD4+ akan semakin tinggi kadar IgG antiToxoplasma, walaupun kekuatannya sangat lemah. Nilai duga negatif yang cukup baik (71\%), setidaknya memiliki arti bagi klinisi bahwa uji ini bias menduga seseorang tidak menderita ET sebesar $71 \%$. Masih dibutuhkan pemeriksaan lanjutan untuk melihat infeksi $T$. gondii pada sampel penelitian ini. Oleh karena itu akan dilanjutkan dengan pemeriksaan PCR Toxoplasma.

Sayangnya, dalam penelitian ini tidak dapat disertakan hasil uji serologi darah Toxoplasma gondii.Studi yang menilai kadar antibodi terhadap T. gondii pada cairan otak masih sangat terbatas. Meira, dkk (2013) [31] menilai kadar IgG anti-Toxoplasma pada cairan otak dengan mengggunakan Excretory/secretory antigen (ESA), yaitu suatu antigen utama yang dihasilkan takizoit pada fase akut. Diharapkan dengan rancangan penelitian yang lebih kompleks, mengikutkan beberapa sentra HIV \& AIDS, dan jumlah sampel yang lebih banyak, dapat menghasilkan hubungan yang bermakna antara variabel pemeriksaan. Apalagi pada penelitian ini ditemukan adanya kecenderungan peningkatan kadar IgG pada beberapa variabel yang dapat membantu menegakkan ET.

\section{References}

[1] Filippini, Massimo, and Lester C. Hunt. (2011) "Energy demand and energy efficiency in the OECD countries: a stochastic demand frontier approach." Energy Journal 32 (2): 59-80.

[2] Filippini, Massimo, and Lester C. Hunt. (2012) "US residential energy demand and energy efficiency: A stochastic demand frontier approach." Energy Economics 34 (5): 1484-1491.

[3] Weyman-Jones, Thomas, Jùlia Mendonça Boucinha, and Catarina Feteira Inàcio. (2015) "Measuring electric energy efficiency in Portuguese households: a tool for energy policy.” Management of Environmental Quality: An International Journal 26 (3): $407-422$.

[4] Saunders, Harry (2009) "Theoretical Foundations of the Rebound Effect”, in Joanne Evans and Lester Hunt (eds) International Handbook on the Economics of Energy, Cheltenham, Edward Elgar

[5] Sorrell, Steve (2009) "The Rebound Effect: definition and estimation", in Joanne Evans and Lester Hunt (eds) International Handbook on the Economics of Energy, Cheltenham, Edward Elgar

[1] Biology Exams 4 U. Different types of Immunoglobulin. $2015 \quad$ Available at www.biologyexams4u.com/2012/11/different-types-ofimmunoglobulins-igg.html (accesed on February 2nd, 2015)

[2] Alfonso Y, Fraga J, et al. (2008) Comparison of four DNA extraction methods from cerebrospinal fluid for the detection of Toxoplasma gondii by polymerase chain reactions in AIDS patients. Med Sci Monit. 14(3), MT1-6

[3] Alfonso Y, Fraga J, et al. (2009) Molecular diagnosis of Toxoplasma gondii infection in cerebrospinal fluid from AIDS patients. Cerebrospinal Fluid Res. 6, 2

[4] Alfonso Y, Fraga J, et al. (2009) Detection of Toxoplasma gondii in cerebrospinal fluid from AIDS patients by nested-PCR and rapid identification of type I allele at B1 gene by RFLP analysis. Exp Parasitol. 122, 203-7

[5] Ashburn D. (1992) "History and General epidemiology”. Human Toxoplasmosis. Ed. Ho-Yen DO, Joss AWL. Oxford : Oxford University Press, $1-25$

[6] Beraud G, Francois P, et al. (2009) Co-trimoxazole for treatment of cerebral toxoplasmosis : An observational cohort study during 19942006. Am J Trop Med Hyg. 80(4), 583-7

[7] Colombo FA, Vidal JE, et al. (2005) Diagnosis of cerebral toxoplasmosis in AIDS patients in Brazil : importance of molecular and immunological methods using peripheral blood samples. J Clin Microbiol. 43(10), 5044-47

[8] Derouin F, Leport C, et al. (1996) Predictive value of Toxoplasma gondii antibody titres on the occurrence of toxoplasmic encephalitis in HIV-infected patients. AIDS. 10, 1521-27

[9] Deisenhammer F, Bartos A, et al. (2011) "Routine Cerebrospinal Fluid (CSF) Analysis". European Handbook of Neurological Management. Ed. Gilhus NE, Barnes MP, Brainin M Volume 1. 2nd ed.Chicester:Blackwell Publishing, 1, 5-17

[10] Diguvinti S, Ramarao P, et al. (2014) Cerebral toxoplasmosis in HIV mimicking as primary CNS lymphoma/tuberculoma : A case report. In J Health Sci Res. 2(3), 867-70 
[11] Ditjen PP \& PL Kemenkes RI. (2014). Statistik Kasus HIV/AIDS di Indonesia. Kementerian Kesehatan Republik Indonesia.

[12] Ellenby MS, Tegtmeyer K, et al. (2006) Lumbar Puncture. N Engl J Med. 355, e12

[13] Evans R. (1992) "Life cycle and animal infection". Human Toxoplasmosis. Ed. Ho-Yen DO, Joss AWL. Oxford : Oxford University press, 26-51

[14] Ferreira MS, Borges AS. (2002) Some aspects of protozoan infections in immunocompromised patients - a review. Mem Inst Oswaldo Cruz. 97(4), 443-457

[15] Filisetti D, Candolfi E. (2004) Immune Response to Toxoplasmagondii. Ann Ist Super Sanita.40(1), 71 - 80

[16] Ganiem AR, Dian S, et al. (2012) Cerebral Toxoplasmosis mimicking subacute meningitis in HIV-infected patients : a cohort study from Indonesia. PloS Negl Trop Dis. 7(1), e1994

[17] George SM, Malik AK, Al Hilli F. (2009) Cerebral toxoplasmosis in an HIV positive patient : A case report and review of pathogenesis and laboratory diagnosis. Bahrain Med Bull. 31(2), 1-5

[18] Grimwade K, Swingler GH. (2009) Co-trimoxazole prophylaxis for opportunistic infectons in adults with HIV. The Cochrane Collaboration.

[19] Hegab SM, Al-Mutawa SA. (2003) Immunopathogenesis of toxoplasmosis. Clin Exp Med.3, 84-105

[20] Imran D. (2007) Cerebral Toxoplasmosis in RSCM Hospital, Jakarta. Neurology Department University of Indonesia. (presentation)

[21] Jayawardena S, Singh S, et al. (2008) Cerebral Toxoplasmosis in adult patients with HIV infection. Hosp Physician. 17-24

[22] Joseph P, Calderon MM, et al. (2002) Optimization and evaluation of PCR assay for detecting

[23] Toxoplasmic encephalitis in patients with AIDS. J Clin Microbiol. 40(12), 4499-503

[24] Kamerkar S, Davis PH. (2012) Toxoplasma on the brain : understanding host-pathogen interactions in chronic CNS infection. J Parasitol Res. 1-10

[25] Kongsiriwattanakul S, Suankratay C. (2001) Central nervous system infections in HIV-infected patients hospitalized at King Chulalongkorn Memorial Hospital. J Med Assoc Thai. 94(5), 551-8

[26] Luft BJ, Chua A. (2000) Central nervous system toxoplasmosis in HIV : pathogenesis, diagnosis, and therapy. Curr Infect Dis. 2, 358-62

[27] Luma HN, Tchaleu BCN, et al. (2013) Toxoplasma encephalitis in HIV/AIDS patients admitted to the Doula general hospital between 2004 and 2009:a cross sectional study. BMC Res Notes 6, 146

[28] Magnero AM, Sini V, et al. (2012) Clinical, brain imaging and therapeutic evaluation of Toxoplasma encephalitis in HIV-infected patients in Yaounde. Retrovirology. 9(Supp 1), P145

[29] Mechain B, Garin YJ, et al. (2000) Lack of utility of spesific Immunoglobulin G antibody avidity for serodiagnosis of reactivated toxoplasmosis in immunocompromised patients. Clin Diagn Lab Immunol. 7, 703-5

[30] Meira CS, Vidal JE, et al. (2011) Immunnodiagnosis in cerebrospinal fluid of cerebral toxoplasmosis and HIV-infected patients using Toxoplasma gondii excreted/secreted antigens. Diagn Microbiol Infect Dis. 71, 279-85

[31] Meira CS, Vidal JE, et al. (2013) IgG4 spesific to Toxoplasma gondii excretory/secretory antigens in serum an/or cerebrospinal fluid support the cerebral toxoplasmosis diagnosis in HIV-infected patients. J Immunol Methods. 395, 21-28

[32] Miller CM, Boulter NR, et al. (2009) The immunobiology of the innate response to Toxoplasma gondiiInt J Parasitol. 39, 23-39

[33] Mittal V, Ichhpujani RL. (2001) Toxoplasmosis-an update. Trop Parasitol. 1(1), 9-14

[34] Montoya JG. (2002) Laboratory diagnosis of Toxoplasma gondii infection and toxoplasmosis. J Infect Dis. 185, 873-82

[35] Montoya JG, Liesenfeld O. (2004) Toxoplasmosis. Lancet. 363, 1965-76

[36] Munoz M, Liesenfeld O, Heimesaat MM. (2011) Immunology of Toxoplasma gondii. Immunol Rev. 240, 269-85

[37] Mzileni MO, Longo-Mbenza B, Chephe TJ. (2008) Mortality and causes of death in HIV-positive patients receiving anti retroviral therapy at Tshepang Clinic in Doctor George Mukhairi Hospital. Polskie Archiwum Medycyny Wwnetrzenej. 118(10), 548-53

[38] Nasronudin. (2007) HIV \& AIDS Pendekatan Biologi Molekuler, Klinis, dan Sosial. Surabaya:Airlangga University Press, 1-12

[39] Nissapatorn V, Lee C, et al. (2004) Toxoplasmosis in HIV/AIDS patients : A current situation. Jpn J Infect Dis. 57, 160-5

[40] Nissapatorn V. (2009) Toxoplasmosis in HIV/AIDS : A Living Legacy. Southeast Asian J Trop Med Public Health. 40(6), 1158-78

[41] Octaviani D. (2013) Respon terapi empiris pada pasien HIV-AIDS yang diduga ensefalitis toksoplasma di RSCM dan faktor yang mempengaruhinya. Departemen Neurologi FKUI.

[42] Pinon JM, Dumon H, et al. (2001) Strategy for Diagnosis of Congenital Toxoplasmosis : Evaluation of methods comparing mothers and newborns and standard methods for postnatal detection of immunoglobulin G,M, and A antibodies. J Clin Microbiol. 39(6), 2267-71

[43] Rajagopalan N, Suchitra JB, Shet A, et al. (2009) Mortality among HIV-infected patients in resource limited settings : A case controlled analysis of in patients at a community care center. Am J Infect Dis. 5(3), 219-24

[44] Remington JS, Thulliez P, Montoya JG. (2001) Recent developments for diagnosis of Toxoplasmosis. J Clin Microbiol. 42(3), 941-5

[45] Robert-Gangneux F, Darde M. (2012) Epidemiology of and diagnostic strategies for Toxoplasmosis. Clin Microbiol Rev. 25(2), 264-96

[46] Sakamoto N, Maeda T, et al. (2014) Clinical presentation and diagnosis of toxoplasmic encephalitis in Japan. Parasitol Int. 63, 701-4

[47] Sarciron ME, Gherardi A. (2000) Cytokines involved in toxoplasmic encephalitis. Scand J Immunol. 52, 534-43

[48] Silaban D, Ritarwan K, Dhanu R. (2008) Ensefalitis toksoplasmosis pada penderita HIV/AIDS. Majalah Kedokteran Nusantara. 41(2), 151-4 
[49] Sukthana Y. Toxoplasmic encephalitis. Available at www.intechopen.com (acessed on December 28th, 2013)

[50] Starkey J, Moritani T, Kirby P. (2014) MRI of CNS fungal infections : Review of aspergillosis to histoplasmosis and everything in between. Clin Neuroradiol. 24, 217-30

[51] Switaj K, Master A, et al. (2005) Recent trends in molecular diagnostic for Toxoplasma gondii infections. Clin Microbiol Infect. 11, 170-6

[52] Tenter AM, Heckeroth AR, Weiss LM. (2000) Toxoplasma gondii : from animals to human. Int J Parasitol. 30, 1217-58

[53] Terazawa A, Muljono R, et al. (2003) High Toxoplasma antibody prevalence among inhabitants in Jakarta, Indonesia. Jpn J Infect Dis. 56, 107-9

[54] Vidal JE, Colombo FA, et al. (2004). PCR assay using cerebrospinal fluid for diagnosis of cerebral toxoplasmosis in Brazilian AIDS patients. J Clin Mcrobiol. 42(10), 4756-68

[55] Wallon M, Franck J, et al. (2010) Accuracy of Real-Time Polymerase Chain Reaction for Toxoplasma gondii in amniotic fluid. Obstet Gynecol. 115(4), 727-33

[56] WHO. (2005) Interim WHO clinical staging of HIV/AIDS and HIV/AIDS care definitions for surveillance.WHO.

[57] WHO. (2006) Guidelines on co-trimoxazole prophylaxia for HIV Related infections among children, adolescent and adults. WHO.

[58] WHO. (2007) HIV/AIDS Programme strengthening health service to fight HIV/AIDS. WHO.

[59] Wig N, Wali JP. (2005) Central Nervous System and HIV/AIDS. JIACM. 5(2), 163-8

[60] Zarrin M, Mahmoudabadi AZ. (2010) Central nervous system fungal infection : A review article. Jundishapur J Microbiol. 3(2), 41-47 